\title{
The Indian diaspora in Africa: the commodification of Hindu Rashtra
}

\author{
Modi, R., \& Taylor, I.
}

\begin{tabular}{|c|c|}
\hline Date of deposit & $08 / 05 / 2017$ \\
\hline Document version & Author's accepted manuscript \\
\hline Access rights & $\begin{array}{l}\text { (C) } 2017 \text { Informa UK Limited, trading as Taylor \& Francis Group. } \\
\text { This work is made available online in accordance with the } \\
\text { publisher's policies. This is the author created, accepted version } \\
\text { manuscript following peer review and may differ slightly from the } \\
\text { final published version. }\end{array}$ \\
\hline $\begin{array}{l}\text { Citation for } \\
\text { published version }\end{array}$ & $\begin{array}{l}\text { Modi, R., \& Taylor, I. (2017). The Indian diaspora in Africa: the } \\
\text { commodification of Hindu Rashtra. Globalizations, Latest Articles. } \\
\text { DOI: } 10.1080 / 14747731.2017 .1287451\end{array}$ \\
\hline $\begin{array}{l}\text { Link to published } \\
\text { version }\end{array}$ & https://dx.doi.org/10.1080/14747731.2017.1287451 \\
\hline
\end{tabular}

Full metadata for this item is available in St Andrews Research

Repository at: https://research-repository.st-andrews.ac.uk/

\section{St Andrews Research Repository}




\section{THE INDIAN DIASPORA IN AFRICA: THE COMMODIFICATION OF HINDU RASHTRA}

Indo-African relations can be traced to ancient times (Beri, 2003) and Africa is host to a longestablished Indian Diaspora (a smaller long-established African Diaspora also exists in India (see Karmwar, 2010)). In the contemporary period however, a new set of dynamics have emerged that have rapidly expanded relations between Africa and India (Taylor, 2012), something which has been relatively recent, with 2005-06 dubbed 'Our Years of Africa' (Suri, 2008: 2). India's trade with Africa has doubled in recent years, from $\$ 24.98$ billion in 2006-07 (Business Day, January 28, 2013) to \$72 billion in 2015 (This Day, March 15, 2016). With Africa being described by previous prime minister Manmohan Singh as 'a major growth pole of the world' (Times of India, May 24, 2011), the continent has been seen as providing political support to India, as well as important opportunities for new investment sites and new export markets (Agrawal, 2007; Biswas, 2016).

The discussion about an Indian diaspora in Africa needs to be placed within this context, with trade and the worth of the diaspora for India's economic growth firmly central. The changes in India's political economy towards greater economic liberalization and the concomitant progressive commercialization of Indian foreign policy are the keys to understanding the current revised interest in the diaspora in Africa. When discussing India's interest in the diaspora today, it is crucial to situate this within the wider context of the adoption, in 1991, of a neoliberal economic policy framework. Since then, the 'Indian leadership [has been] determined to plunge into the liberalization, privatization, globalization bandwagon' (Vivek, 2005: 560). Having moved from the slow "Hindu rate of growth," India's recent economic trajectory has propelled this diplomacy and it is within this broader milieu that Indian policies towards the diaspora should be contextualized. New Delhi's elites actively seek to embrace an objectified "globalization" as a means to benefit powerful externally-oriented fractions and the diaspora's value is measured in its contribution to this project.

This article thus seeks to look at the evolving approach to the notional Indian diaspora in Africa, noting the sea-change in attitudes towards persons of Indian decent in recent years by the government in New Delhi, as well as the attempt to commodify this diaspora to serve Indian economic interests. The diaspora in South Africa is discussed as an example where these dynamics can be acutely observed. 
As has been noted by others given their international location, diasporas are suitably apposite as a means to engineer and manipulate international images and thus to spotlight attention on the issue of what constitutes identity (Shain and Barth, 2003). In this context, the exclusionary approach to Indian identity (and thus what constitutes a "real" Indian) by the current Indian government, one which prioritizes "Hindu Rashtra" (i.e. the Hindu nation) whilst embracing neoliberal globalization, is seen as contradictory and problematic.

\section{The Indian diaspora in question}

The study of diasporas is a growing academic field, with India's being no exception (see Motwani et al., 1993; Dubey, 2003; Jayaram, 2004; Lal et al., 2006; Sahay, 2009). A key characteristic of diaspora is a culture of desire for the notional homeland, while the more identifiable location for identity and living is the actual place of dwelling. This has been called a "homing" tendency wherein, 'The concept of diaspora places the discourse of 'home' and 'dispersion' in creative tension, inscribing a homing desire while simultaneously critiquing discourses of fixed origins' (Brah, 1996: 192-193). "Home" then can be both material and imagined; both are "real". Home becomes politicized with regard to power and identity, and at the same time, multi-scalar in nature (Blunt and Dowling, 2006). Because of the objective distance between home and dispersion, alongside the idealized desire for return, diasporas are often considered to possess an "imagined" home (Blunt, 2003; George, 2003; Veronis, 2007). Yet because of the heterogeneity of diasporas, tensions may develop between groups within the diaspora who differ in their attitude and relationship to the homeland". This may be due to differences in class, religion, regional origin etc. as well as the different temporal moments when separate members or their families left the homeland. When generational distance becomes greater, the appearance of alternative imagined (and often highly romanticized) homelands tends to develop (see Yeh, 2005).

Before discussing any notional Indian diaspora however, some key issues need to be flagged up. Firstly, the very idea of an Indian diaspora in Africa is often cast as self-evident and common sense. Analysis then starts from a position which serves to reify, rather than reflect on, the issue at hand. Groups are classified without any rigorous definition of what exactly is a diaspora (see e.g. Singhvi, 2001; Sahoo, 2007). Yet given the fact that the majority of so-called Indians in Africa left the sub-continent before partition, an "Indian" i.e. a Republic of India diaspora, cannot be unquestionably assumed. Clearly, the complicated realities of the Indian diasporic identifications, which are often not aligned to the modern space today known 
as "India", means that outreach to these communities are unlikely to always resonate (McCann, 2010).

Secondly, the sense of community is often assumed when no such thing may exist. The focus in diaspora studies has at times been on 'how the diaspora experience is embedded in the complexities of class, race, gender, generation and other social divisions' (Jazeel, 2006). This tendency essentializes diasporic identities yet such a homogenizing conception of a diaspora obscures inner stratification of the groups in terms of class, caste, ethnic and regional origins (Jacobsen and Kumar, 2004). The Indian diaspora is no exception and in fact, caste and religious differences are profound. Thirdly, an a-historical perspective is often adopted which assumes the permanence of the transnational groups' identity, regardless of the period during which migration occurred or how long the diaspora has been in existence (Vertovec, 1991). An automatic and ready identification with India is often assumed, although why this should be the case is rather strange. These issues will all be discussed below, but fit with Gijsbert Oonk's wider question about the limits of the Indian diaspora as an intellectual concept (see Oonk, 2007).

In general geographic distribution, the overseas Indian community is clearly not homogeneous and at least six phases of outmigration can be distinguished:

(i) merchants who went to East Africa or South-East Asia before the 16th century;

(ii) migration of various groups (traders, farmers) to neighboring countries (Ceylon, Nepal, Burma etc.);

(iii) indentured laborers to colonial possessions in the West Indies, Fiji, Mauritius or Natal; as well as migration through middlemen to Malaya;

(iv) migration of skilled/semi-skilled workers after the Second World War towards the developed countries (primarily the United Kingdom);

(v) migration of contract workers to the Persian Gulf;

(vi) contemporary migration of Information Technology workers to developed countries (primarily the USA) (Lessinger, 2003).

For the purpose of this article, diasporan status is not assumed to be automatically based on the location of a specific community outside its notional "homeland", but rather "diasporan" identity requires active involvement and identification (Tölölyan, 1996). It is this understanding that underpins this article's discussion of Indian diasporic communities in Africa. 


\section{The Indian diaspora in Africa: history and origins}

Contact between India and Africa is long established and Indian trade with the eastern African seaboard is ancient (Prasad, 2003). Colonization led to the incorporation of the Indian subcontinent and large swathes of Africa into the British Empire, which then facilitated the establishment of a substantial Indian Diaspora in Africa, which constitutes a radical difference between India and most other international actors involved in Africa. The prime dynamic for this was indentured labor, which was a form of debt bondage, by which 3.5 million Indians were transported to various colonies by the European imperialists to provide labor for the (mainly sugar) plantations (see; Malherbe, 1991; Jain, 1993; Carter, 1995; Lal, 2000; Mishra, 2009; Desai and Vahed, 2010).

As the national movement developed in India, the "overseas Indians" played an important role, with struggles against the indentured labor system and then against discrimination of Indians in the colonies being prominent. Specifically with regard to indentured labor, the regime began to be seen as a significant issue in the fight against British imperialism. As late as 1893, Mahadev Govind Ranade a leading nationalist at the time and a founding member of the Indian National Congress, still believed that 'Indian foreign emigration' afforded some 'relief' to the growing population of India, and that thus the expansion of the British Empire could be seen as a 'direct gain' to the Indian masses as territorial expansion of the Empire meant new opportunities for India's poor. However, in 1896 Mohandas K. Gandhi met with Gopal Krishna Gokhale and tried to interest him in the cause of overseas Indians. Gandhi, who was living in South Africa and practicing law at the time, tried to convince other nationalists of the necessity to abolish indenture. The situation of the "coolies" was greatly dramatized during Gandhi's Satyagraha campaign in South Africa, who denounced the complacent attitude of the colonial South African government to the dire condition of many Indians in Natal (Emmer, 1986: 200). Abolition of indentured labor was demanded, which finally took place in 1916, bringing an end to the exportation of Indian labor.

It might be said that the first time that the "Indians" beyond the borders of the country were thought about in a systematic fashion was during the struggle for Indian independence. ${ }^{1}$ As the Indian national movement gained substantial traction, overseas Indians were definitely seen as part of a future free Indian nation. The most notable formulation of such ideas was by

\footnotetext{
${ }^{1}$ So as to avoid repetitive and intrusive scare quotation marks, the term "Indians" will henceforth be left unmarked. This in no way implies ignoring the fact that many of the Indian diaspora's roots originate from either what were then princely states or what are now Bangladesh, Pakistan etc.
} 
Mohandas Gandhi. His first encounter with what constituted "Indianness" was whilst abroad and was essentially an umbrella epithet for uniting the diverse groups of Indian migrants in South Africa. In Gandhi's own narrative, this “Indianness" evolved subtly, deploying prenational categories based on essentially primordial identities which solidified through exilic experiences. The evolution from clans to a "nation", was for Gandhi culturally grounded. This concept made spatial location unimportant in a general sense as there was no 'free India' at the time that could delimit borders and thus serve as a process of exclusion (Nataryan, 2013).

Though there was little pressure on the migrants to return "home", there were appeals to them to identify with the nationalist cause, which would in the long run also be of advantage to them as 'only a free India [could] hope to protect and safeguard the interests of Indians abroad' (Gangulee, 1947:14). The overseas Indians were asked 'to identify with the exploited and not with the oppressors' (ibid., 10) and develop 'a feeling of unity with the land of their adoption' (ibid., 11). For such Indian nationalists as Nagendranath Gangulee therefore, the Indian nation extended beyond territory. India was presented thus not as a territorial entity, but as a deterritorialized state - an idea. Many nationalists in India at this time embraced the concept in which overseas Indians were part of a (future) free nation.

However, after 1947, the inclusive ideas around what constituted Indianness-and particularly with regard to the overseas Indians-were essentially shelved and a policy of 'studied indifference' (Parekh 1993:38) was adopted. The first Prime Minister of India, Jawaharlal Nehru, led this shift because, unlike Gandhi, Nehru did not see overseas Indians as belonging to the Indian nation. As far as Nehru was concerned, 'expatriate Indians had forfeited their Indian citizenship and identity by moving abroad and did not need the support of their mother country'. Only those residing within India's new borders were "truly" Indian and overseas Indians were counselled to identify with where they lived and not with India. As a result, overseas Indians were not part of India's diplomacy (Lall 2001:41). The official policy of Nehru (quoted in ibid., 169) was basically:

It is the consistent policy of the government that persons of Indian origin who have taken foreign nationality should identify themselves with and integrate in the mainstream of social and political life of the country of their domicile. The government naturally remains alive to their interests and general welfare and encourages cultural contacts with them. As far as Indian citizens residing abroad are concerned, they are the responsibility of the government of India. 
Within this Nehruvian worldview, dual citizenship was impossible. Either they assumed citizenship of the other country, or they were to remain Indians minus the rights of citizenship. According to Nehru, people should identify with one place only, namely where they lived. The Citizenship Act that was passed in 1955 and removed the right, which had been provided in the constitution, of Indians overseas to citizenship. 'Ultimately and predictably, a territorially based 'nativist' nationality emerged to preclude extra-territorial citizenship' (Sutton, 2007: 286-287).

Consequently, "overseas Indians" were no longer an integral part of the wider Indian nation, although somewhat contradictorily, Nehru believed that 'Wherever in this world there goes an Indian, there is also a bit of India with him' (quoted in Gupta 1994:1). Yet Nehru then demanded of them that they 'forget their separate identities' (Ibid: 15). This had more to do with Nehru's foreign policy of non-alignment and South-South solidarity. People of Indian descent, particularly in East Africa, were not particularly popular and were often accused of being aloof and even racist towards Africans. Nehru's vision of a postcolonial world united for independence could not abide the possibilities of disunity. Thus he was keen to reiterate that the Indian community in South Africa were not Indians and needed to identify with the African majority:

The question of Indians, though important to us, has been deliberately allowed by us to become a secondary issue to the larger issue of racial discrimination. The opposition movement there is far more African than Indian. The leadership is African - we want it to be so. We have told Indians in Africa very definitely and very precisely that we do not encourage or support them in anything they might want which goes against the interest of Africans (quoted in Vahed, 2015: 70-71).

This was greeted with unease in some quarters of the South African Indian community who felt that the problems of Indians in South Africa were being 'submerged in the vaster race problems of all Africa and in the debating exchanges of the United Nations, where the practical issues facing South African Indians have been dissolved into the larger questions of world policy and diplomacy.' (ibid.: 71). Yet Nehru was adamant on this point and later reassert that 'we have told the Indians there year after year...they must co-operate with the Africans...we will not support them in their demand for any privilege that goes against the Africans. If you can't get on with the Africans, you'll have to get out of Africa....that's what we have told our 
Indian' (quoted in Oonk, 2013: 211). The last thing Nehru wanted was the Indian diaspora disrupting or undermining his status as a putative leader of the postcolonial world.

Yet, it is not quite as clear-cut as this and a recent discovery in the South African archives by Vineet Thakur, a postdoctoral research fellow at the University of Johannesburg, has raised a most intriguing issue. Thakur has found a document from South Africa's representative at the United Nations, G.P. Jooste, dated October 24, 1949, in which Jooste records a meeting with Sir B.N. Rau, India's permanent representative to the UN. After discussing how caste legislation was threatening the rule of the Brahmins, Rau is quoted as stating that the 'Indians who went to South Africa did not belong to the best type and that, as in Burma, they may have exploited the local population and given India a bad name'. Rau went on to suggest that the way Pretoria treated them 'might be fully justified and that in fact India would not mind discrimination against our local Indian community if only it was not based on racial lines' (Thakur, 2016).

What Rau suggested was that if a limited number of high caste Indians were granted equal citizenship rights in South Africa, this would in effect denote that there was no discrimination against Indians based on race. Rau's position was clearly based on the presupposition that it was upper caste Indians who represented the best of India and so should be seen as its authentic representatives. By implication, lower caste Indians were not genuine ambassadors for India and thus the way they were handled by Pretoria was irrelevant. Whilst there are of course limitations to the analogy, it is the case that Modi's ideological position visa-vis who constitutes the real India (Hindus) similarly introduces a problematic bifurcation in the diaspora, something discussed below.

\section{Defining the diaspora}

In line with the wider question of identity, in the immediate post-partition period there was a strong attempt to delineate Indianness. Those abroad seeking registration as citizens of the Republic of India, were to accept the ideas of the Indian Constitution and to work towards the objectives set forth in it. In practice, this meant a commitment to secularism and a rejection of confessional identities. In fact, when two hundred application forms for citizenship registration were requested in Kenya by the Ismailia Council, the Indian High Commission in Nairobi replied with a letter questioning the credibility of potential applicants 'to become citizens of India, a State founded on the principle of secularism and non-communal ideologies' (cited in 
Rao, 1951). Combined with Nehru's stance on the diaspora, it was not until the early 1970s that there was any expression of interest by New Delhi in the Indians abroad (Dickinson, 2012).

Evolution of a diaspora policy was slow coming. In 1973, the Indian government inaugurated the category of Non-resident Indian (NRI) within the Foreign Exchange Regulation Act (FERA) (Banerjea and Mukherjea 1975). This defined NRIs as:

(i) Indian citizens who stay abroad for employment or for carrying on a business or vocation or any other purpose in circumstances indicating an indefinite period of stay abroad.

(ii) Indian citizens working abroad on assignment with foreign government agencies like United Nations Organisation (UNO), including its affiliates, International Monetary Fund (IMF), World Bank etc.

(iii) Officials of Central and State Government and Public Sector undertakings deputed abroad on temporary assignments or posted to their offices, including Indian diplomatic missions, abroad.

The main goal of FERA was to regulate foreign ownership of companies operating within India during a period when import substitution was a key element of the New Delhi's development policies. The point of the NRI provision was to classify Indian individuals located outside of India as non-foreigners for the purposes of investment and proprietorship. Yet, for the first time, special exceptions for Indians abroad were granted.

When the Janata government under Morarji Desai took power in 1977, some further changes in policy towards the overseas Indians were introduced. New entry laws were brought in that allowed overseas Indians to return to India to live, even if citizens of another country. Atal Bihari Vajpayee (then Minister for Foreign Affairs) asserted that India would 'never disown overseas Indians, or fail to appreciate their loyalty to the motherland' (cited in Punathambekar, 2013: 28). New Delhi began sponsoring discussions on "Overseas Indians" and the Indian Council for Cultural Relations was mandated to engage with the diaspora. A cell within the Ministry of External Affairs was reevaluated to serve the overseas Indians better. The Friends of India Society International meanwhile argued for a separate government department for overseas Indian affairs.

As the government in New Delhi sought to encourage the development of networks of support amongst the diaspora, a rejection of Nehruvian ideas was manifest. Nehru's policy was 
in fact felt to be 'confused, erratic and apathetic' (Bahadur Singh, 1979: 326). Markedly, in 1979, academics working on the diaspora such as I.J. Bahadur Singh argued that the 'Indian diaspora was part of India' [emphasis added]. Singh in fact proposed a utilitarian approach to the diaspora, suggesting that 'It would only be natural for us to turn to the one resource on which we have a national claim and are endowed with resources. Sentimentally they also would like to give first preference to India' (1979: 217). This claim of an emotional attachment to the "motherland" which would then result in financial largesse flowing back to India went untested and rested on some pretty big assumptions as evinced in the case of the South African Indian diaspora in particular (see below).

However, there was a qualitative shift in attitude. The old Nehruvian view on 'Overseas Indians' was replaced by a new discourse on 'People of Indian Origin' (formalized in 1998) (Brown, 2006). This change in itself was a return back to Gandhi's viewpoint that had included the Indian diaspora, though this time it was less to do with a romantic idea of what constituted India and more to do with the desire to 'tap into the investible funds of the PIOs' (Xavier 2015: 24). This has created an interesting dialectic. For New Delhi, the linkages between the diaspora and the 'homeland' are characterized mainly by relationships of remittances, investments and economic exchanges whilst for the diaspora, it is generally 'the emotional attachment through feeling concerned about India, especially among the first generation PIOs' (ibid: 25). Somewhat controversially, the new discourse now asserted that groups settled in a place are not necessarily of it. This has a two-edged sword to it. Firstly, in this way certain groups (such as religious minorities), could henceforth be delineated as being somehow 'outside the nation'. Conversely, the "right sort of Indian" abroad, though actually residing beyond India's borders, could be included.

As has been noted, the new approach to India's diaspora has taken place within the wider context of the adoption, in 1991, of a neoliberal economic policy framework. '[T] his shift was a momentous development and a leading World Bank economist reportedly celebrated it as among the "three most important events of the twentieth century", alongside the collapse of the Soviet Union and China's transition to "market reforms" (Jha, 2005: 3677). For others, it is 'probably the most significant [discontinuity] since the country's independence from colonial rule in 1947' (Mazumdar, 2014: 79). Thus in recent years, 'in a globalised context, private business enterprises have...become the standard bearers of "nationalism", "national interest" and "national achievement" so that national success tends to be seen as something that 
coincides with their success' (Mazumdar, 2014: 95). This is where the diaspora come in vis-avis current Indian policies towards Africa.

\section{The BJP approach}

With the takeover by the BJP coalition in 1998 after two United Front coalitions, the narrative of the nation unquestionably changed, as well as the understood role of the Indian diaspora in building this new India. The Bharatiya Janata Party (BJP) has had more developed plans for the diaspora than previous governments. In an outline of its Foreign Policy and Agenda for the Future (1995:6-7) it was stated:

A more meaningful support to Indians living abroad whenever their basic human rights are violated is experienced from the BJP by the people in India and outside, so that Uganda and Fiji experiences are not repeated. The BJP is fully alive to its responsibility. The people of Indian origin living abroad are an asset, which the BJP would try to utilize to the fullest extent to foster relations of friendship and cooperation between the countries of their residence and India. The BJP will seriously examine the question of dual citizenship to NRIs.

Previously, Atal Bihari Vajpayee (BJP prime minister of India, 1998-2004) when minister for external affairs in the Janata government (1977-1979) had pushed for a different attitude towards the diaspora. During a conference in 1977, Vajpayee critiqued Nehru's policy and asserted that 'every Indian community overseas, whether rich or poor, needs to maintain contacts with India'. A culturalist approach (with reference to their "distinctive Indian personality") was adopted and in the Chennai Declaration of the BJP it was stated that "We believe that the vast community of NRIs and PIOs also constitute a part of the Great Indian Family. We should endeavor to continually strengthen their social, cultural, economic and emotional ties with their mother country' (quoted in Lall, 2001:98). ${ }^{2}$ But equally, a pragmatic business-oriented motive was also averred, with him stating that Indians in the developed and some parts of the underdeveloped world have capital and know-how, which could help India's economic development (Bahadur Singh, 1979).

2 The Chennai Declaration emanated from a meeting by the BJP's National Executive Committee in 1999, whereby amendments to the party's constitution were adopted. The Declaration inter alia claimed that the BJP had given up its Hindutva agenda and sought support from all quarters to "make the 21st Century India's century". 
The political elites in New Delhi have reclaimed the diaspora and has fashioned the notion of a deterritorialized nation state based on "Indianness" which means that the Indian nation exists wherever the diaspora does (Schiller et al., 1999: 78-79). This is very much in line with the BJP's foundational Hindutva ideology which inter alia, asserts that Indians (in practice, Hindus) are those who believe India is their fatherland (pitribhumi) and holy land (punyabhumi) and call for the creation of a "Hindu Nation" (Hindu Rashtra) (see Udayakumar, 2005). Now, PIOs are referred to as the "natural reserve" where there is an urgent need to tap their potential for the nation. PIOs are seen as key as a means to attract inward investment into India, as evinced by the enthusiastic subscriptions to the India Development Bonds (19901991), the Resurgent India Bonds (1998) and the India Millennium Deposit scheme (2000) of the State Bank of India (Xavier in Rahman and Yong 2015: 24-25). The PIOs can also springboard the country's markets wherever they are residents. Liberalization has made the transfer of remittances easier and 'India is opportunistically using directives of the International Monetary Fund (IMF) and the World Bank on freer exchange regulations to encourage more Non-Resident Indians (NRIs) and PIOs to remit and invest funds in order to raise the level of remittances and investments from outside its own borders' (Singh, 2011: 32). Under the neo-liberal regime the commodification of people of Indian origin as a "resource" is quite explicit and the current government has clearly 'prioritized some communities of Indians living overseas over others in terms of their ability to brush some of their "new colors onto the ever-evolving canvas of India's development"” (Edwards, 2008: 458).

Underlying this new interest in (and recasting of) the diaspora is both the Hindutva claim on all Hindus as Indians and, more prosaically, the desire to attract inward investment into India and to expand the country's markets where PIOs are resident. But of course, this now only really applies to where spending power is present. Thus, subtle moves have been made which whilst on the face of it appear universal, actually discriminate in favor of richer diasporan Indians. For example, in January 2005 it was announced that dual citizenship would be extended to all overseas Indians who had migrated from India after 26 January 1950. This temporally-limited restriction obviously meant that dual citizenship offer in practice was only being offered to those migrants who had emigrated recently to the West. Clearly, the less affluent descendants of indentured laborers (whose association with the homeland was, in any case, separated by many decades of exile), was of no priority. In helping to facilitate the exploitation of the identified "useful diaspora", liberalization has made the transfer of remittances easier. In this sense, 'India is opportunistically using directives of the International 
Monetary Fund (IMF) and the World Bank on freer exchange regulations to encourage more Non-Resident Indians (NRIs) and PIOs to remit and invest funds in order to raise the level of remittances and investments from outside its own borders' (Singh, 2011: 32). Under the neoliberal regime the commodification of people of Indian origin (of the right sort) as a "resource" has been quite explicit.

Beyond the clear favoring of the relatively more wealthy parts of the diaspora, who constitutes the Indian nation abroad is however deeply problematic given the government's cultural policies. The identification by Delhi regarding those sons and daughters who can claim Bharat Mata as their own is inherently political and has become ever more so with a Hindu chauvinist party in power. The reason for this is ideological and can trace its roots to the formulations about India drawn up by the intellectual antecedents of the BJP. Of note, Madhav Sadashiv Golwalkar, a founding figure of the Rashtriya Swayamsevak Sangh (RSS) and revered by his ideological heirs as "Guruji" declared that:

The non-Hindu peoples of Hindustan must either adopt the Hindu culture and language, must learn to respect and hold in reverence Hindu religion, must entertain no idea but the glorification of the Hindu race and culture... [In] a word they must cease to be foreigners, or may stay in the country wholly subordinated to the Hindu nation, claiming nothing, deserving no privileges, far less any preferential treatment - not even citizen's rights (quoted in Bhatt, 2001: 130).

This exclusivist stance is not mere a historical curiosity, irrelevant to modern-day India. As is well known, in his book Jyotipunj (Modi, 2015) the current prime minister of India, Narendra Modi, wrote the life stories of sixteen men who inspired him. All sixteen were members of the Rashtriya Swayamsevak Sangh (RSS), an organization derided as exhibiting "buffalo nationalism" and "spiritual fascism" (Ilaiah, 2012). The longest biography in the book is of Golwalkar, who in the original Hindi version of the book (published in 2008) is styled as Pujniya Shri Guruji i.e. Guru Worthy of Worship (in the English version, Golwalkar is titled 'The Honourable Guruji'). In other words and to put it into its proper context regarding the idea of the Indian nation either at home or abroad, the current prime minister of India wrote a hagiography of a politician who asserted that non-Hindus can only remain in the country as second-class citizens 'deserving no privileges', 'not even citizen's rights'. As of the latest Indian census (2011), this segment of the population 'deserving no privileges' amounts to over 244 millions. 


\section{How "Indian" are PIOs?}

As has been noted, since the 1990s, the Indian government has sought to re-engage people who it views as PIOs. The policy has been aimed particularly at such people living in the developed world, highlighting the business-oriented nature of this new interest. To reconnect with the diaspora, New Delhi has progressively introduced several initiatives, such as the setting up of a High Level Committee on the Indian Diaspora (HLCID) in January 2002, the introduction of measures to ease visa applications, initially through the PIO card scheme and now the Overseas Citizenship of India (OCI) card (the PIO cards were withdrawn as of 9th January 2015 and deemed to be now OCI cards). Furthermore, to publicly acknowledge the contribution made by the select diaspora to India, the Pravasi Bharatiya Divas (PBD) has been held every year in January since 2003 (Dickinson, 2012).

The PBD awards are sponsored by the Ministry of Overseas Indian Affairs, the Federation of Indian Chambers of Commerce and Industry, the Confederation of Indian Industry, and the Ministry of Development of the North Eastern Region of India. The awards meeting recognises specific contributions of NRI/PIO individuals to India and are used as a forum to deliberate on issues of concern for people in the diaspora. Of course, who is selected for the awards and who represents the diaspora is a moot point. Brij Maharaj is highly critical of this initiative, rejecting it as 'an expensive public relations exercise' (Maharaj, 2012: 86). The Ministry of Overseas Indian Affairs nonetheless works towards strengthening India's linkages with her supposed diaspora through various novel initiatives such as the 'know India programme', 'tracing your roots' and organizing regional 'mini PBD's as outreach programmes for those not able to attend the main event in India.

However, utilizing this imagined community is not as clear-cut as first may be supposed. The actual identity of who belongs to Bharat Mata remains open to interrogation, particularly under the BJP which, as pointed out above, has its ideological origins in a very narrow Hindu chauvinism. Indeed, 'the rise of the BJP in India had been congruent with a BJP-led reimagining of the Indian state', one which is 'a powerfully globalizing state which was also distinctly Indian, due to its organization around a distinctive, strong, internal understanding of Hindutva or Hindu cultural identity' (Edwards, 2008: 456). The whole PIO enterprise under the BJP then is not targeted at the Indian diaspora as a whole, despite the official policy that a person of Indian origin (PIO) is 'a citizen of any country other than Bangladesh, Pakistan or Sri Lanka, if he at any time held an Indian passport, or he, either his parent or any of his grand- 
parents, was a citizen of India, or the person is spouse of an Indian citizen' (Indian Investment Centre, www.iic.in, cited in Landy et al., 2004: 204). Despite the claim that Hindu Rashtra is made up of those who accept India as their ancestral homeland, only certain sons and daughters are of interest.

It is certainly not the lower-class migrant laborers in the Gulf region who are included in this nation and nor is it the generally poor (or at least less affluent) Indians in Guyana or South Africa and elsewhere. Even the older merchant communities that form the bulk of the diaspora in East Africa are not much of interest. Rather, it is the new middle-class professional and entrepreneurial migrants especially in the United States that forms an important focus for Indian politics (van der Veer 2005: 285). Indeed, there is an unspoken hierarchy (dare we say it, caste?) which underpins this notional Indian nation outside India. One's worth within this nation is dependent upon what an individual can do for the continuing neoliberal capitalist accumulation strategy of the government in New Delhi. Thus as Edwards notes (2008: 46) 'membership of the 'Global Indian' "cosmopolitan community" proved to have strategically selected economic (highly skilled professional migrants) territorial (the United States and Western Europe) and ethnic (Hindu) dimensions'.

This exclusionary vision has been made quite explicit by the High Level Committee on the Indian Diaspora which links such wealthy individuals to the discourse of India's rise as a nation. The committee noted that 'India's emergence as a modern society, destined to play a role in knowledge-based industries, particularly in the field of information technology ... has helped to change the image of the Indian Diaspora globally'. Unambiguously, the development of a professional class of Indian immigrants in the United States, Canada, and United Kingdom was linked to India's 'resurgence as a global player and as a country of stature in the comity of nations' (High Level Committee on the Indian Diaspora, 2001: vii). Notably however, the policy recommendations of the committee were to construct a conceptualization of the Indian diaspora as a deterritorialized and globalized Hindu nation, made up of PIOs and NRIs (Edwards, 2008). It is no surprise then that Indians in the USA have been observed as some of the most vigorous in their support of both the BJP and the more militant Vishwa Hindu Parishad (World Hindu Council), an organization that was established for promoting Hinduism around the world (Biswas, 2005: 56).

In the African context, this limited vision of what constitutes a valuable member of the diaspora is perhaps just as well as the Indianness of PIOs in Africa cannot be taken for granted. Indeed, just because one's great-great-grandfather may have come from country $\mathrm{x}$ does not 
mean that one is likely to hold any meaningful link to the "motherland" beyond some idealized notions and perhaps a proclivity for various cultural attributes (food, dance etc.). An exhaustive treatment of the entirety of the diaspora across Africa is beyond the scope this article. However, the Indian diaspora in South Africa is most instructive in this regard, as they constitute the largest Indian diaspora outside of India.

\section{The South African situation}

When we consider Indian South Africans, well over 95 percent regard English as their first language and most speak no vernacular Indian languages at all (Vahed and Desai, 2010). Additionally, well over one quarter of Indian South Africans have converted to Christianity and caste is not that important for marriage. Cuisine, dress, and other markers of "Indianness" have mutated into something as quintessentially South African as "bunny chow. ${ }^{3}$ Concrete Indian identity is somewhat vague. In a survey performed in South Africa, out of 213 Indian respondents, between 15 and 17 year old, $80 \%$ did not know from where their ancestors came in India. Out of the 198 students who disclosed their religion, 37\% of the Muslims knew their Indian place of origin, while only $19 \%$ of the Hindus and $4 \%$ of the Christians were aware of their geographical roots (Mainet-Valleix, 2002).

Rehana Vally, a South African academic of Indian descent has debunked the myth about "Indians" in the country as a homogeneous community, by offering insights into the debates surrounding the commemoration of 150 years on Indian presence in South Africa in 2010. She discussed the controversies, dissensions and lack of homogeneity among the Indian community in Laudium, the Indian township of Pretoria where she conducted her study. The community was divided sharply along lines of religion, language and place of origin (in the Indian sub-continent) and the centenary proved that the Indian communities living in Laudium had grown distant from each other, with most retaining an attachment to India which was merely culturally symbolic. At heart they saw themselves as South Africans first and foremost (Vally, 2012: 76). Brij Maharaj, an academic at the University of KwaZulu Natal has equally talked about Indian South Africans' link to India as 'abstract, spiritual... which many pilgrims find disappointing as faith has been commodified' (Maharaj, 2012: 87).

Particularly after the 1994 non-racial elections and the promotion of the idea of the "Rainbow Nation", some South Africans of Indian descent even reject this vague notion of Indianness:

\footnotetext{
${ }^{3}$ A hollowed out loaf of bread filled with curry, originating from Durban.
} 
We are not Indian. Our race may be stated as 'Indian' on official documents, but we are South African. Most of our families have been in this country for up to seven generations. Most of us have not even been to India. The term 'Indian' is for (ugh) classification purposes. I personally do not like being referred to as another nationality entirely just because of my heritage. I am as South African as wors (Ramkissoon, 2012).

The questions around identity in fact has been a recurrent theme, with most rejecting a specific Indian personality:

I am an African, full stop .... I eat my samp with curry and Mohammed Rafi sits happily alongside Mfaz'onyama in my music collection. My parents and theirs were born on this continent and this is where they took their last breaths. My children and theirs have this land ... as their birthright...My ancestors' roots are in India. My roots are here. I am a South African citizen - I have the opportunities today that my parents never had. These institutions are ours, too (Kiru Naidu, political columnist, Natal Mercury, 29 July 2010: 7 in Steibel, 2011: 80 cited in Modi 2014).

Indeed, the grand-daughter of Mahatma Gandhi, Ela Gandhi, born and brought up in South Africa has this to say about her Indian identity: 'I am a South African. A very proud South African...The Indianness comes in at the level of...culture... the kinds of things we appreciate like music, drama... What I am basically saying [is] that is where the Indianness stops (Quoted in Dupelia-Mesthrie, 2000: 9). The Report of the High Level Committee on the Indian Diaspora, conducted by New Delhi's Ministry of External Affairs in fact found 'ample evidence in South Africa to corroborate the fact that the PIOs in this country are South Africans, first and foremost. The fact that they look like us, very often eat the same kind of food, and have many of the cultural values that we cherish, does not make them a little more Indian than South African. A century and a half of existence in an alien land, and four or five generations of acculturation in a dominant White society, has diluted their Indianness' (High Level Committee on the Indian Diaspora, 2001: 84).

This takes us back to the exploration of what is Indian in the South African context? For the ancestors of South African Indians that migrated from the Raj i.e. prior to 1947, territory was fixed. But for those born and brought up in South Africa, and who have never visited India or even intend to do so, do they then constitute a "diaspora"? Whilst the diaspora has become a crucial politico-economic agenda for the current Indian government, its very existence as an utilisable vehicle is in some doubt (Dickinson, 2012). Certainly, due to their heterogeneity and 
generational remoteness from India, South African Indians generally recognize that there is no identity between India as a country and any form that constitutes an Indian. In other words, and contra to the BJP position on the Indian nation, for Indian South Africans 'there is no unitary culture in India which can be termed Indian culture' (Jayaram, 1998: 56). Hence it is very difficult for Indian South Africans to consider themselves as "Indians". The diverse nature of the Indian communities in South Africa exacerbates this problem as 'South African Indian identities are always configured by multiple determinants such as indenture, migration for commercial purposes, language, religion, gender, and class. As a vastly heterogeneous community, speaking in tongues as varied as Gujarati, Tamil, Hindi, and Urdu, and also belonging to different religious faiths, South African Indians are marked more by difference than by similarity' (Rastogi, 2008: 11).

At the same time, however, "Indianness" becomes very flexible and fragmented. It is not the case that Indian South Africans totally disregard their Indian roots. India (or at least its idea) is still a referent, but this is all very transcendental, possessing an abstract existence (Landy et al., 2004). This was most graphically seen during the July 2016 visit by Modi to South Africa. The diversity of opinion within the South African Indian community, both positive and negative, was quite apparent and highlighted some of the contradictions that have been discussed.

Modi's two-day visit to South Africa was part of a four nation tour of Africa (Mozambique, South Africa, Tanzania and Kenya). The visit was very much cast as being aimed at boosting trade and deepening engagement in defence production, manufacturing, mining and minerals. Two separate events underlined the contested nature of the diaspora in South Africa. At one event, in the commercial heart of South Africa (if not Africa), Modi addressed more than 11,000 members of the Indian community at a stadium in Johannesburg. In this speech, Modi reached out to the diaspora, highlighting the business opportunities that were available and how Delhi was seeking to facilitate this:

A resurgent India awaits you. And, we have taken several steps towards eliminating barriers of entry. The OCI and PIO schemes have been rolled into one. In February this year we launched e-visa for South Africa. You can now get Indian visa sitting at home in your email, and that too at no cost! Brothers and Sisters, India and South Africa have much to benefit from a closer partnership. You are a window to India's heritage, to our ethos and to our values. And, you form an important life line for our ties with this land (Modi, 2016). 
The event had been organized by a self-appointed SAWelcomesModi Committee. This fourmember committee's make-up was of great interest and quite revealing. Membership of the committee was made up of: Raman Dhawan, Chief Executive Officer of Tata Africa Holdings and an Indian national; Sayed Hoosen Mia, a Johannesburg-based businessman; Akhtar Thokan, a Johannesburg-based businessman; and Mukesh Patel from the Shree Baps Swaminarayan Mandir, a Hindu organization. Thus prominent businessmen of possible usage to Indian capitalism were prioritized, alongside a representative of a Hindu proselytization body. One would never know that in fact, the majority of Indian South Africans are not Hindu. What these individuals represented in fact was the reality that 'there remains a socio-economic hierarchy inside the South African Indian community. At the top is an elite group of businessorientated Indians, many of whom acquired large amounts of wealth and social standing during Apartheid based on exploitative relationships with other Indians as well as Africans' (Dickinson, no date: 6).

Whilst Modi was received with considerable enthusiasm in both Johannesburg and KwaZulu Natal, criticism was also evident, with varying motives evident. On the one hand, Modi was critiqued for only meeting on a one-to-one basis 'the usual tenderpreneurs, funders and corrupt officials' (The Mercury (Durban), July 11, 2016). Others were critical of Modi's 'exclusivist ideology based on Hindu nationalism and an Indian state founded on a single, dominant religion' (City Press (Johannesburg), July 5, 2016).

It was in KwaZulu Natal however that Modi both experienced rapturous welcome as well as opprobrium. Taking a train from Durban to Pietermaritzburg, ostensibly to honour the journey Gandhi had embarked on in 1893 before being thrown off by police for being in a Whites-only carriage, Modi then visited Phoenix, about 20km north of Durban, to visit the Gandhi settlement where he had lived and started his printing press. Whilst Modi sought to link himself with Gandhi, local commentators were quick to point out Modi's association with the RSS and the fact that it was an RSS member who had been responsible for Gandhi's assassination (Mercury (Durban), July 14, 2016). As the influential Mail and Guardian newspaper noted, 'The RSS...reportedly distributed sweets when Gandhi was killed by an RSS devotee in 1948' (Mail and Guardian (Johannesburg) July 14, 2016).

At the same time, Modi's identification with Gandhi reinvigorated a wider debate about the Mahatma in South Africa which had risen to prominence after the October 2015 publication of Ashwin Desai and Goolam Vahed's book, The South African Gandhi. Stretcher 
Bearer of Empire. The authors 'punctures the dominant narrative of Gandhi and uncovers an ambiguous figure whose time on African soil was marked by a desire to seek the integration of Indians, minus many basic rights, into the White body politic while simultaneously excluding Africans from his moral compass and political ideals' (Desai and Vahed, 2015).

This revisionism of Gandhi alongside the drawing of attention to Modi's chauvinist credentials was certainly not what had been planned and although local newspapers were replete with letters from readers complaining about the "Hindu-bashing" that had accompanied Modi's visit, it was quite clear that the Indian community in South Africa was very much divided in their approach to the Indian prime minister's outreach to them. The easy association of the diaspora in South Africa with a divisive figure such as Modi, despite his attempt to prioritise economic opportunities that awaited them in India, clearly proved problematic.

The Modi visit demonstrated that at best we can say that a socially shared cultural Indianness 'is a product of the past rather than a desire to come closer to the real India' (ibid.: 214). Given that the current government narrowly defines Indianness within a Hindu frame, South African Indianness is not something that the idea of the PIO as a resource can really tap into and it is something which many South African Indians reject. As Amitav Ghosh has put it, the relationship between the modern Indian state and diasporic Indians is a "historical anomaly" given that Indians abroad and Indians in India share very little in terms of language, religion, caste, or kinship, Ghosh asserts in fact that assumed relationship between India and its diasporas is void of serious systems of social and cultural reproduction and that 'the simple fact [is] that the links between India and her diaspora are lived within the imagination' (Ghosh, 2002: 10).

\section{Conclusion}

There is at present a great interest within India in what are termed People of Indian Origin in Africa. Around 10 per cent of the global Indian Diaspora is located in Africa (Dubey, 2010) and these are relatively assimilated. According to one study, 'in a 2006 survey of 450 business owners in Africa, almost half the respondents who were ethnically Indian had taken on African nationalities (with most of the other half retaining their Indian nationality), compared with only four per cent of firm owners who were ethnically Chinese (the other $96 \%$ had retained their Chinese nationality)' (Broadman, 2008: 99). PIOs are currently seen by New Delhi as having the potential ability to facilitate cooperation and communication between Africa and India, as well as serve as economic agents for Indian commercial interests. 
This last point needs to be carefully managed by New Delhi as historic resentment against economically powerful ethnic Indians has long been a feature of a number of African countries - and is something which will not be helped by any notion that such actors are somehow advancing India's agenda in any form. After all, Paul Theroux (1967) started his famous article on the Indian question in Kenya with the statement that 'In East Africa nearly everyone hates the Asian'. Concerning Uganda, the Asians were an intermediary class, the 'petty bourgeoisie', playing the vital role of linking the African producer with metropolitan (British) capital. Not only this, but: "The petty bourgeoisie in the colony had, for political reasons, to be an ethnically alien petty bourgeoisie", because such a category could 'easily be segregated from the mass of the colonised and thus rendered politically safe' (Mamdani, 1976: 71).

In South Africa, relations between the Indian community and the African majority can be fraught. Although many Indians played an active role in the anti-apartheid struggle, with some rising to senior posts within the African National Congress and then the post-1994 government, dealings on the ground may be different. On the one hand 'The majority of Indians in SA are racist. It is sad but true. Many of the older generation Indian citizens became very used to the way life was during the apartheid days (especially the fact that in the race hierarchy, the Black people were below them) that they find it difficult to experience a total reverse in hierarchy since 1994' (Rastogi, 2008: 163). On the other, a growing Africanist trend in South Africa politics has taken at times an anti-Indian position. In KwaZulu Natal, for an example, a group calling itself Mazibuye African Forum has called for the "liberation of KwaZulu-Natal from Indians' and has demanded that Indian-owned land be distributed to Africans and for South African Indians to lose their status as being classified previously disadvantaged and thus the benefits that may accrue from the government's Black Economic Empowerment scheme. Equally, the Economic Freedom Fighters (EFF) leader Julius Malema, raised what he called the "Indian question" in KwaZulu-Natal during interviews taking place in Cape Town for the vacant deputy judge president position in that division. According to Malema, 'the Africans feel Indians are dominating life in every sphere' (Mail and Guardian, October 15, 2015).

Latent anti-Indian sentiment has of late crystallised around President Jacob Zuma's intimate relationship with the Gupta family, a business family from Delhi. Resentment against the Guptas has focused on perceived sweetheart business deals related to their mining interests, or administrative favours, with outcries over mines operating without the necessary water use licences; questions over a large contract to supply the state power utility with coal; and public 
consternation over permission granted to land a large party of wedding guests at a military air force base. The South African deputy finance minister Mcebisi Jonas was recorded as stating that the Guptas — and not Zuma - had offered him a cabinet position. The scandal around the role of the Guptas led to a highly damning official report from the former Public Protector Thuli Madonsela being released in October 2016 (Public Protector of South Africa, 2014). The report outlined in detail just how much control the Gupta family had over South Africa's resources and offered proof that Zuma had sanctioned the use of state companies for personal enrichment for himself and the Guptas. Of course, none of this was mentioned during Modi's visit to South Africa.

As has been detailed, India's attempts to create links with its diaspora have undergone various stages and have been directly influenced by India's changing domestic political landscape. In the early postcolonial period, Jawaharlal Nehru was pre-occupied with domestic growth and South-South solidarity. For these reasons, Nehru distanced New Delhi from the Indian diaspora. This was particularly the case in East Africa where the concerns of Indian traders clashed with African nationalism. It was this nationalism and the move towards independence that Nehru was concerned about. In turn, ambivalence and even antipathy towards India by East African Indians was common. Many felt abandoned by the motherland in the face of prejudice within Africa. It is notable that when Indians in Africa experienced difficulties (including actual, expulsion in the case of Uganda), they went anywhere but India (only 4,500 opted to go to India from Uganda).

Liberalization in 1991 changed the attitude towards Indians abroad in New Delhi. This combined with the emergence of Hindu nationalism. From the 1970s onwards, Hindu rightists had fundraised within overseas Indian communities and had expressed a more inclusive (whilst actually being exclusive) attitude towards Indians abroad compared to Nehru. The electoral victory of the BJP enabled this to be institutionalized and the BJP government then offered a Persons of Indian Origin (PIO) card, which furnished holders with multi-entry visas and certain commercial rights in India.

Of late, the Indian government is noticeably engaging the Indian diaspora in Africa. Indian corporations and officials are increasingly enthusiastic by the economic and political potential of relations with the South and the diaspora is now seen as a major resource that should be tapped into. Indians abroad in places such as South Africa are being cast as possible lubricators of relations. However, challenges remain. The aloofness between Africa's Indians and India remains. Even if African Indians today no longer feel abandoned by India, as many 
of their parents did in the 1960s-1970s, the relative lack of contact with India from the 1960s dictated onwards that their gaze is much more towards London or Toronto than it is to New Delhi or Mumbai. Few South African Indians thus far have demonstrated much interest in the resurgent India, other than opportunistic businessmen attracted to India's economic opportunities. This has much to do with Pretoria's enthusiastic promotion of both IBSA (see Taylor, 2009) and BRICS and the subsequent publicity that this garners. But the paramount identity of South African Indians is their South Africanness. An Indian diasporic cultural diplomacy that is built on Hindutva (even if only in the background) is unlikely to resonate very far.

In short, while India's dynamic diasporic transitions in theory provide potential for India's ruling elites and selected overseas Indians (i.e. the wealthy ones), we should not intuitively assume that diasporic-cultural linkages in Africa automatically provide India with advantages in its overseas activities. The post-colonial history of India-diaspora relations, as well as the place and self-identity of overseas Indian communities within certain African societies, South Africa being a notable example, have produced complex situations that need much greater analysis than a blithe acceptance of the trope regarding India's "children" overseas. The "other India" as postulated by Bahadur Singh cannot be assumed.

\section{Bibliography}

Agrawal, S. (2007) Emerging Donors in International Assistance: The India Case Ottawa: IDRC-Partnership and Business Development Division.

Alden, C. and A. Viera (2005) 'The New Diplomacy of the South: South Africa, Brazil, India and Trilateralism,' Third World Quarterly, vol. 26, no. 7.

Alesina, A. and Dollar, D. (2000), 'Who Gives Foreign Aid to Whom and Why?', Journal of Economic Growth, vol. 5.

Bahadur Singh, I. (ed.) (1979) The Other India: The Overseas Indians and their Relationship with India New Delhi: Heinemann.

Banerjea, Pramathanan and Mukherjea (eds.) (1975) Foreign Exchange Regulation Act, 1973 Calcutta: International Law Book Centre.

Bava, U. (2007) 'New Powers for Global Change? India's Role in the Emerging Global Order', Dialogue on Globalization Briefing Papers no. 4, New Delhi: Friedrich Ebert Stiftung.

Beri, R. (2003) 'India's Africa Policy in the Post-Cold War Era: An Assessment,' Strategic Analysis, vol. 27, no.2. 
Bhaduri, A. (2010) Essays in the Reconstruction of Political Economy Delhi: Aakar Books.

Bhatt, C. (2001) Hindu Nationalism Origins, Ideologies and Modern Myths New York: Oxford University Press, 2001

Bhattacharya, S. (2010) 'Engaging Africa: India's Interests in the African Continent, Past and Present' in Cheru, F. and Obi, C. (eds.) The Rise of China and India in Africa London: Zed Books.

Biswas, A. (2016) 'Indian Investors Seeking Markets and Business Prospects' in Dubey, A. and Biswas, A. (eds.) India and Africa's Partnership: A Vision for a New Future New York: Springer.

Biswas S. (2005) 'Globalisation and the Nation Beyond: The Indian-American Diaspora and the Rethinking of Territory, Citizenship and Democracy', New Political Science, vol. 27, no. 1 .

Blunt, A. (2003) 'Geographies of Diaspora and Mixed Descent: Anglo-Indians in India and Britain', International Journal of Population Geography, vol. 9, issue 1.

Blunt, A., \& Dowling, R. (2006) Home London: Routledge.

Brah, A. (1996) Cartographies of Diaspora: Contesting Identities New York: Routledge.

Broadman, H. (2007) Africa's Silk Road: China and India's New Economic Frontier Washington, DC: World Bank.

Broadman, H. (2008) 'China and India Go to Africa: New Deals in the Developing World,' Foreign Affairs, vol. 87, no. 2.

Brown, J. (2006) Global South Asians: Introducing the Modern Diaspora Cambridge: Cambridge University Press.

Carter, M. (1995) Servants, Sirdars and Settlers: Indians in Mauritius, 1834 - 1874 Delhi: Oxford University Press.

Carter M. (1996) Voices from Indenture. Experiences of Indian Migrants in the British Empire London: Leicester University Press.

Chiriyankandath, J. (2004) 'Realigning India: Indian Foreign Policy After the Cold War,' Round Table, vol. 93, no. 372.

Desai, A. and Vahed, G. (2010) Inside Indian Indenture: A South African Story, 1860-1914 Pretoria: HSRC Press.

Desai, A. and Vahed, G. (2015) The South African Gandhi: Stretcher-Bearer of Empire Stanford, CA: Stanford University Press.

Desai, R. (2007) 'Dreaming in Technicolour? India as a BRIC', International Journal, vol. 62, 
no. 4.

Desai, M. (2012) 'Parties and the Articulation of Neoliberalism: From "The Emergency" to Reforms in India, 1975-1991' in Go, J. (ed.) Political Power and Social Theory, volume 23 Bingley: Emerald Group Publishing.

Dickinson, J. (no date) 'A Profile of South Asians in Kenya and South Africa', unpublished paper.

Dickinson, J. (2012) 'Decolonising the Diaspora: Neo-colonial Performances of Indian History in East Africa: Decolonising the Diaspora', Transactions of the Institute of British Geographers, vol. 37, issue 4.

Drèze, J. and Sen, A. (2013) An Uncertain Glory: India and its Contradictions London: Allen Lane.

Dubey, A. (2003) Indian Diaspora: Global Identity New Delhi: Kalinga Publications.

Dubey, A. (2010) Indian Diaspora in Africa: A Comparative Perspective New Delhi: MD Publications.

Dupelia-Mesthrie, U. (2000) From Canefields to Freedom Cape Town: Nationale Bookhandel.

Edwards, K. (2008) 'For a Geohistorical Cosmopolitanism: Postcolonial State Strategies, Cosmopolitan Communities, and the Production of the "British", "Overseas", "NonResident", and "Global" "Indian", Environment and Planning D: Society and Space, vol. 26.

Emmer, P. (1986) 'The Meek Hindu; the Recruitment of Indian Indentured Labourers for Services Overseas, 1870-1916' in Emmer, P C (ed.) Colonialism and Migration; Indentured Labour before and after Slavery Dordrecht: Martinus Nijhoff.

Gangulee, N (1947) Indians in the Empire Overseas: A Survey London: New India Publishing House.

George, R. (2003) 'Of Fictional Cities and "Diasporic" Aesthetics', Antipode, vol. 35, no. 3.

Ghosh, A. (2002) 'The Diaspora in Indian Culture' in The Imam and the Indian: Prose Pieces New Delhi: Ravi Dayal.

Ghosh, A. (2006) 'Pathways Through Financial Crisis: India', Global Governance: A Review of Multilateralism and International Organizations, vol. 12, no. 4.

Gregory, R. (1963) Quest for Equality: Asian Politics in East Africa, 1900- 1967 New York: Orient Longman.

High Level Committee on the Indian Diaspora (2001) Report of the High Level Committee on the Indian Diaspora New Delhi: Indian Council of World Affairs 
Hurrell, A. and Narlikar, A. (2006) 'A New Politics of Confrontation? Developing Countries at Cancun and Beyond', Global Society, vol.20, no.4.

Ilaiah, K. (2012) Buffalo Nationalism: A Critique of Spiritual Fascism Kolkata: Samya.

Jacobsen, K. and Kumar, P. (eds.) (2004) South Asians in the Diaspora. Histories and Religious Traditions Leiden: Brill.

Jain, P. (1993) 'The Socio-Economic History of Indians in Kenya' in Motwani, J. (ed.) Global Indian Diaspora: Yesterday, Today and Tomorrow New York: Global Organization of People of Indian Origin.

Jayaram, N. (1998) 'Social construction of the other Indian: encounters between Indian nationals and diasporic Indians', Journal of Social and Economic Development, vol. 1. Jayaram, N. (ed.) (2004) The Indian Diaspora: Dynamics of Migration New Delhi: Sage Publications.

Jazeel, T. (2006) 'Postcolonial Geographies of Privilege: Diaspora Space, the Politics of Personhood and the 'Sri Lankan Women's Association in the UK', Transactions of the Institute of British Geographers, 31.

Jha, P. (2005) 'Withering Commitments and Weakening Progress State and Education in the Era of Neoliberal Reforms', Economic and Political Weekly, August 13.

Jobelius, M. (2007) 'New Powers for Global Change? Challenges for International Development Cooperation: The Case of India', Dialogue on Globalization Briefing Papers, no. 5, New Delhi: Friedrich Ebert Stiftung.

Karmwar, M. (2010) 'African Diaspora in India', Diaspora Studies, vol. 3, no. 1.

Kuper, H. (1960) Indian People in Natal Westport: Greenwood Press.

Lal, B. (2000) Chalo Jahaji: On a Journey of Indenture Through Fiji (Suva: Fiji Museum, 2000).

Lal, Brij V., Peter Reeves and Rajesh Rai (eds.) (2006) The Encyclopaedia of the Indian Diaspora Singapore: Editions Didier Millet in association with National University of Singapore.

Lall, M. (2001) India's Missed Opportunity: India's Relationship with the Non-Resident Indians Aldershot: Ashgate.

Landy, F., Maharaj, B. and Mainet-Valleix, H. (2004) 'Are people of Indian origin (PIO) “'Indian"? A case study of South Africa', Geoforum, vol. 35.

Lemon, A. (1990) 'The Political Position of Indians in South Africa' in Clarke, C. (ed.) South Asian Overseas: Migration and Ethnicity Cambridge: Cambridge University Press. 
Lessinger, J. (2003) 'Indian immigrants in the United States: the emergence of a transnational population' in Parekh, B., Singh, G. and Vertovec, S. (eds.) Culture and Economy in the Indian Diaspora London: Routledge.

Maharaj, B. (2012) 'Commemoration, Celebration or Commiseration? 150th Anniversary of Indentured Labourers in South Africa' in Patel, S. and Uys, T. (eds.) Contemporary India and South Africa Legacies, Identities, Dilemmas London: Routledge.

Mainet-Valleix, H. (2002) Durban, les Indiens, leurs territoires, leur identite Paris: Karthala.

Malherbe V. (1991) 'Indentured and Unfree Labour in South Africa: Towards an Understanding', South African Historical Journal, vol. 24.

Mamdani, M. (1976) Politics and class formation in Uganda London: Heinemann.

Mazumdar, S. (2014) 'Continuity and Change in Indian Capitalism' in Becker, U. (ed.) The BRICS and Emerging Economies in Comparative Perspective: Political Economy, Liberalisation and Institutional Change London: Routledge.

McCann, G. (2010) 'Ties that Bind or Binds that Tie? India's African Engagements and the Political Economy of Kenya', Review of African Political Economy, 37.

Mishra, A. (2009) 'Indian Indentured Labourers in Mauritius: Reassessing the "New System of Slavery” vs. Free Labour Debate', Studies in History, vol. 25, no. 2.

Mukherjee, P. (2008) 'Opening Address by Shri Pranab Mukherjee, External Affairs at the India Africa Forum Summit, New Delhi', April 7.

Modi, N. (2015) Jyotipunj New Delhi: Prabhat Prakashan.

Modi, N. (2016) 'India is a Ray of Hope, Says Prime Minister Modi in Johannesburg', July 8, http://www.narendramodi.in/pm-modi-at-an-interaction-with-indian-community-insouth-africa-499189

Motwani, J.K, Mahin Gosine, R Jyoti Barot Motwani. (eds.) (1993) Global Indian Diaspora: Yesterday, Today \& Tomorrow New York: GOPIO.

Mundkur, B. (2011) 'Incredible India: The Inconvenient Truth', Asian Affairs, vol. 42, no. 1.

Naidu, S. (2007) 'India's African Relations: Playing Catch Up with the Dragon', Los Angeles: Globalization Research Center: African Studies Center, UCLA.

Naidu, S. (2008) 'India's Growing African Strategy', Review of African Political Economy, vol.35, no.1.

Natarajan, N. (2013) Atlantic Gandhi: The Mahatma Overseas New Delhi: Sage Publications India. 
Nayar, B. and T. Paul (2003) India in the World Order: Searching for Major Power Status Cambridge: Cambridge University Press.

Ollapally, D. and Rajagopalan, R. (2012) 'India: Foreign Policy Perspectives of an Ambiguous Power' in Nau, H. and Ollapally, D. (eds.) Worldviews of Aspiring Powers: Domestic Foreign Policy Debates in China, India, Iran, Japan and Russia Oxford: Oxford University Press.

Oonk, G. (2007) Global Indian Diasporas: Exploring Trajectories of Migration and Theory Amsterdam: Amsterdam University Press.

Oonk, G. (2013) Settled Strangers: Asian Business Elites in East Africa (1800-2000) New York: Sage Publications

Parekh, B (1993) 'Some Reflections on the Indian Diaspora', paper presented at the Second Global Convention of People of Indian Origin, December 27-31, New Delhi.

Park, R. (1965) 'Indian-African Relations', Asian Survey, vol.5 no.7.

Prasad, P. (2003) Foreign Trade and Commerce in Ancient India New Delhi: Abhinav Publications.

Public Protector of South Africa (2016) State of Capture: Report on an Investigation into Alleged Improper and Unethical Conduct by the President and Other State Functionaries Relating to Alleged Improper Relationships and Involvement of the Gupta Family in the Removal and Appointment of Ministers and Directors of StateOwned Enterprises Resulting in Improper and Possibly Corrupt Award of State Contracts and Benefits to the Gupta Family's Businesses Pretoria: Public Protector of South Africa

Punathambekar, A. (2013) From Bombay to Bollywood: The Making of a Global Media Industry New York: New York University Press.

Ramkissoon, N. (2012) 'The mystical nature of the Indian South African', Sunday Times (Johannesburg), 9 January.

Rao, J. (1951) First Secretary, Indian High Commission, Nairobi, to Ministry of External Affairs, 2 December, AII/52/ 6423/31, National Archives of India.

Rastogi, P. (2008) Afrindian Fictions Diaspora, Race, and National Desire in South Africa Columbus, OH: Ohio State University Press.

Research Unit for Political Economy (2005) 'Why the US Promotes India's Great-Power Ambitions', Aspects of India's Economy, no. 41, December. 
Sahay, A. (2009) Indian Diaspora in the United States: Brain Drain or Gain Lanham: Lexington Books.

Sahoo, S. (2007) 'Socio-Cultural Linkages Between Indian Diaspora', in Jain, P. (ed.) Diaspora and Transnational Communities New Delhi: IGNOU.

Sahni, V. (2007) 'India’s Foreign Policy: Key Drivers', South African Journal of International Affairs, vol. 14, no. 2.

Schiller, N., Basch, L. and Blanc, C. (1999) 'From Immigrant to Transmigrant: Theorising Transnational Migration' in Pries, L. (ed.) Migration and Transnational Social Spaces Aldershot: Ashgate.

Shain, Y. and Barth, A. (2003) 'Diasporas and International Relations Theory', International Organization, vol. 57, no. 3.

Sharma, A. (2007) 'India and Africa: Partnership in the 21st Century', South African Journal of International Affairs, 14, no. 2.

Shastri, V. (1997) 'The Politics of Economic Liberalization in India', Contemporary South Asia, vol. 6, no. 1.

Singh, R. (2006) 'India, Africa Ready to Embrace Global Destiny', press release January, 25, New Delhi: Ministry of External Affairs.

Singh, A. (2011) 'The PBD Africa: A Catalyst for Brand India in Indo-South African Relations, or an Expansion of Indian Nationalism?' Diaspora Studies, vol. 4, no. 1.

Singh, B. (ed.) (1979) The Other India: The Overseas Indians and their Relationship with India New Delhi: Heinemann.

Singhvi, L. (2001) High Commission Report on Indian Diaspora New Delhi: Government of India.

Suri, N. (2008) 'India and Africa: A Contemporary Perspective', in Sheth, V. (ed.) India-Africa Relations: Emerging Policy and Development Perspectives, pp. 1-16. Delhi: Academic Excellence.

Sutton, D. (2007) 'Divided and Uncertain Loyalties', Interventions: International Journal of Postcolonial Studies, vol. 9, no. 2.

Tata Group (2008) 'About Us: Tata Group Profile', www.tata.com

Taylor, I. (2009) “"The South Will Rise Again”? New Alliances and Global Governance: The India-Brazil-South Africa Dialogue Forum', Politikon: South African Journal of Political Science, vol. 36, issue 1. 
Taylor, I. (2012) 'India's Rise in Africa', International Affairs, vol. 88, no. 4. Thakur, V. (2016) 'When India Proposed a Casteist Solution to South Africa's Racist Problem' < http://thewire.in/27045/exploring-casteism-in-indias-foreign-policy/>,

Theroux, P. (1967) 'Hating the Asian', Transition, no. 33.

Tinker, H. (1977) The Banyan Tree: Overseas Emigrants from India, Pakistan and Bangladesh London: Oxford University Press.

Tölölyan, K. (1996) 'Rethinking Diaspora(s): Stateless Power in the Transnational Moment', Diaspora, 5.

Udayakumar, S. (2005). Presenting the Past: Anxious History and Ancient Future in Hindutva India. Westport, CT: Greenwood Publishing Group.

Vahed, G. (2015) 'Nehru is Just Another Coolie': India and South Africa at the United Nations, 1946-1955', Alternation, Special Edition no. 15.

van der Veer, P. (2005) 'Virtual India: Indian IT Labour and the Nation-State' in Hansen, T. and Stepputat, F. (eds.) Sovereign Bodies: Citizens, Migrants, and States in the Postcolonial World Princeton: Princeton University Press.

Vally, R. (2012) 'Made in India, Proudly South African: Commemorating 150 Years of Indian Presence in South Africa' in Patel, S. and Uys, T. (eds.) Contemporary India and South Africa Legacies, Identities, Dilemmas London: Routledge.

Vanaik, A. (2004) 'The Politics of Neoliberalism in India', Alternative Regionalisms, January 1.

Veronis, L. (2007) 'Strategic Spatial Essentialism: Latin Americans' Real and Imagined Geographies of Belonging in Toronto', Cultural Geography, vol. 8, no. 3.

Vertovec, S. (ed.) (1991) Aspects of South Asian Diaspora Delhi: Oxford University Press.

Vivek, P. (2005) 'India's Public Policy: Issues and Challenges and BRICS' in Ribeiro, G., Dwyer, T., Borgas, A. and Viola, E. (eds.) Social, Political and Cultural Challenges of the BRICS Bamenda: Langaa RPCIG.

Yeh, E. (2005) 'Exile Meets Homeland: Politics, Performance, and Authenticity in the Tibetan Diaspora', Environment and Planning D: Society and Space, vol. 25, no. 4. 